\title{
Correction to: Observations from the 26th November 2019 Albania earthquake: the earthquake engineering field investigation team (EEFIT) mission
}

\author{
Fabio Freddi ${ }^{1}$ (D) Viviana Novelli ${ }^{2} \cdot$ Roberto Gentile $^{1,3} \cdot$ Enes Veliu $^{4} \cdot$ Stoyan Andreev $^{5}$. \\ Anton Andonov ${ }^{5} \cdot$ Federica Greco $^{6} \cdot$ Emiljano Zhuleku $^{7}$
}

Published online: 13 April 2021

(c) Springer Nature B.V. 2021

\section{Correction to: Bulletin of Earthquake Engineering (2021) 19:2013-2044 https://doi.org/10.1007/s10518-021-01062-8}

The Editor-in-Chief alerted the authors that proper attribution needs to be given to below reference, which will be added the list of References.

The figure legend for Fig. 1 should read as follows:

Fig. 1 Albanian earthquake sequence of 2019 and visited locations during the EEFIT mission (EDSF active fault traces adapted from Basili et al. 2013)

\section{Reference}

Basili R., Kastelic V., Demircioglu M. B., Garcia Moreno D., Nemser E. S., Petricca P., Sboras S. P., Besana-Ostman G. M., Cabral J., Camelbeeck T., Caputo R., Danciu L., Domac H., Fonseca J., GarcíaMayordomo J., Giardini D., Glavatovic B., Gulen L., Ince Y., Pavlides S., Sesetyan K., Tarabusi G., Tiberti M. M., Utkucu M., Valensise G., Vanneste K., Vilanova S., Wössner J. (2013). The European Database of Seismogenic Faults (EDSF) compiled in the framework of the Project SHARE. http://diss. rm.ingv.it/share-edsf/, https://doi.org/10.6092/INGV.IT-SHARE-EDSF.

The original article can be found online at https://doi.org/10.1007/s10518-021-01062-8.

Fabio Freddi

f.freddi@ucl.ac.uk

1 Department of Civil, Environmental and Geomatic Engineering, University College London, London, UK

2 School of Engineering, Cardiff University, Cardiff, UK

3 Institute for Risk and Disaster Reduction, University College London, London, UK

4 Scuola Universitaria Superiore IUSS Pavia, Pavia, Italy

5 Mott MacDonald, Sofia, Bulgaria

6 Advance Technology and Research Team, ARUP, London, UK

7 Mott MacDonald, Tirana, Albania 
Publisher's Note Springer Nature remains neutral with regard to jurisdictional claims in published maps and institutional affiliations. 